\title{
KRETEK CULTURE IN ROADSIDE: Honey or Poison?
}

\author{
Erik Aditia Ismaya1, Wasino ${ }^{2}$, Tri Marhaeni P. Astuti. ${ }^{3}$, Etty Soesilowati ${ }^{4}$ \\ ${ }^{1)}$ Elementary Teacher Education Department, Universitas Muria Kudus \\ 1) Social Studies Department, Universitas Negeri Semarang \\ 2) Social History at History Department, Universitas Negeri Semarang \\ 3) Antrhopology at Sociology and Anthropology Department, Universitas Negeri Semarang \\ 4) Public Policy at Economic Development Department, Universitas Negeri Semarang \\ ${ }^{1}$ Corresponding email: erik.aditia@umk.ac.id
}

\begin{abstract}
The purpose of this research is to find and analyze the meaning variation of Kudus society to kretek culture in the framework of healthy and sick concept. Research data were analyzed using social construction theory from Berger and Luckmann. This research uses qualitative approach with case study method and phenomenology research type. Researchers as the main instrument to interview and observe the activities of informants. Data analysis was done through inductive-descriptive-verificative-analysis. The data analyzed by using Creswell model. The results showed that there is a fundamental difference between theory and the results of research on the meaning of the Kudus society to the kretek culture in the framework of the concept of healthy and sick. Informant initials AK who has a history of heart disease (bypass heart) revealed that one method of treatment of heart disease suffered is by sucking kretek herbs. In one day AK can spend eight to ten sticks of kretek herbs. AK said that he felt better after taking the method. Informant initials SR who has a history of weak heart and gout states that every day he still enjoys kretek as much as 12 to 18 cigarettes. SR said that he stopped enjoying kretek only when hospitalized. For SR, enjoying kretek can reduce the tension in working. Informant initials IF said that enjoying kretek that can generate ideas. IF told me that he was once convicted of bronchitis and had time to stop enjoying kretek. But in fact, IF cannot escape to enjoy kretek.
\end{abstract}

Keywords: Kretek Culture, Healthy, Sick

\section{Introduction}

Kretek culture as stated in Hanusz (2003) was a culture that developed in Central Java, located in Kudus.

The word kretek describes an indigenous Indonesian tobacco product containing tobacco, cloves and flavoring, wrapped in either an ironed cornhusk or a slip of paper. It is widely believed that the name derives from the crackling sound that cloves make when burned "kretek-kretek". The first kretek was created in the town of Kudus, Central Java in the late nineteenth century.

Hanusz's view of kretek culture suggests that the approach to explaining kretek culture is to use a materialist perspective. Kretek material form as infrastructure in Kudus society play a role in producing culture that is kretek culture. Kretek culture is the fruit of humans in the form of kretek cigarettes in response to the challenges of nature and the influences of the times that hinder the progress of human life toward a happy and happy life.
Kretek culture that integrates in the daily life of some Kudus society in fact not free from opposition that is the statement that the culture kretek interfere health and cause death. The statement was supported by Barber 2008 research; Khorman and Peter Benson 2011; WHO 2013; Indonesia's Tobacco Atlas Document 2013 Edition; Alzyoud et al 2014; Shadid and Hossain 2015; and Egbe et al 2016.

Kretek culture statement to interfere with health and cause death contrary to the passion of some Kudus people enjoy kretek cigarettes. Results of Riset Kesehatan Dasar 2007 (2007) mention that the most popular type of cigarette is kretek with filter (64.5\%). The Indonesia Tobacco Atlas Document 2013 edition (2013) notes "the number of clove cigarettes produced in 2010 reached 144.2 billion cigarettes for machine cigarettes and 87.2 billion cigarettes for hand-rolled cigarettes".

The phenomenon of pro and contra against kretek culture makes the researcher assume that "there is a construction behind the emergence of pro and contra phenomenon against kretek culture which is intentionally built by pro group and counter group". On the basis of the above 
assumptions, the main question in this study is how the interpretation of the Kudus society to the kretek culture in the framework of the concept of healthy and sick?

\section{Method}

This research uses a qualitative approach with field study method and type of phenomenology research. The main informants of this research are AK (Lecturer), SR (Private Employee), and IF (Lecturer). Secondary data of research are books, journals, government documents and reports relating to research problems.

The researcher itself is the primary data gathering instrument. Interview guides, observation guides, recorders, and field notes are secondary data collection instruments. Interviews and observations were made to key informants. Focus group discussion conducted by researchers with observers of kretek culture and peers.

Data analysis was done through inductive descriptive - verivicative analysis. Data analysis is performed at the time of data collection, and after the completion of data collection within a certain period. In this research used Creswell model data analysis model.

\section{Result and Discussion}

Talking about people's view of healthy and sick body criteria is not always objective. Even more element of subjectivity in determining the condition of one's body. Public perception about healthy and sick is very influenced by the element of past experience, in addition to sociocultural elements.

In sociology, there are some conceptual thoughts that are very influential in healthy analysis and pain. The conflict approach sees the concept of health and illness as a dominance of the ruling group of the ruled. Meanwhile, the functional approach considers the concept of health and pain as a system, so that when there is a sick part of the subsystem the other will immediately adjust to returning to a healthy state (balanced).

Anthropology has a different approach to the concept of health and illness. Approach to the concept of healthy and ill divided into two, namely the ethical approach and approach emik. In ethics, the World Health Organization (WHO) declares health is "a state of complete physical, mental, and social well being, and not merely the absence of disease or infirmity"
(WHO, 1981). Meanwhile, Indonesian Health Law Number 36 Year 2009 states health is a healthy state, both physically, mentally, spiritually and socially that allows everyone to live productively socially and economically. Sarwono (1993) mentions the concept of illness as follows "scientifically disease (disease) is defined as a disturbance of the physiological function of an organism as a result of infection or pressure from the environment, so the disease is objective. Instead, illness is an individual's assessment of the experience of suffering from a disease.

The concept of healthy and sick if associated with the emic approach to a community that bears their cultural concept then there are differences in response to the concept of healthy and sick. This is because of the different knowledge on the concept of healthy although it will be obvious that someone is ethically declared unhealthy but still can perform other social activities. This means that the person can claim to be healthy.

Kretek culture that is considered to interfere with health and cause death and supported data of research results in reality different from the reality of the field. Ismaya et al (2018) find Kretek culture Kudus society that formed around the year 1880 when Hajj Djamhari accidentally found a concoction of clove cigarettes that was efficacious to reduce even cure asthma suffered by quickly spread and loved the Kudus society. Meanwhile, Sutiman (2011) stated "the creation of a kretek cigarette made by our ancestors was not without basis. Cigarettes kretek made for cough medicine ".

The findings of Ismaya et al (2018) and Sutiman's (2011) statement are evidenced by the results of the interviews to the AK stating

" I have heart disease and have undergone heart bypass surgery four times. Look at my chest (while unbuttoning), it's like the Avanza car has entered my heart because its operating costs are over 150 million. But I am still smoking (smoked clove) herbs because this is a cure for my heart disease. In one day I can spend eight to ten stems and feel my body healthier. Yes, it is expensive, but how else am I a heavy smoker. I used to spend two to three packs of cigarettes (kretek cigarettes and white cigarettes) in a day so that until now cannot leave a cigarette. Fortunately, there is a herbal cigarettes that at once be a cure for me "(Interview date at February 14, 2018). 
AK statement is almost similar to that of SR which states

ah ... healthy or sick I'm still smoking (kretek). I just quit smoking if I am hospitalized. I have a history of weak heart and gout. Every day I keep smoking between 12 and 18 cigarettes. Especially if it's a lot of work, for me smoking can reduce tension (Interview dated March 3, 2018).

Meanwhile, IF suggests :

For me to enjoy kretek it can generate ideas and reduce the tension at work. I was once convicted of bronchitis and wanted to stop enjoying cigarettes but until now could not. I just changed my cigarette from the usual mild (Interview dated March 13, 2018).

The statements and experiences of the three informants above prove that health and illness are subjective experiences. Moreover, if it is associated with a statement about kretek culture that interferes with health and causes death. The fact that three informants have a history of ethical illness (medical) is not directly proportional to the consumption of their daily clove cigarettes and they remain healthy.

The conflict perspective in health sociology does not apply to informants. The applicable is the functionalist perspective that if the culture kretek interferes with health and cause death then in kretek culture there must be a functioning heal.

The healthy and sick concepts prevailing in society according to Berger and Luckmann are objective reality but the subjective experience of the informants shows that not all objectives are accepted unanimously. The informant's experience of kretek culture in the concept of health and illness can be explained dialectically through externalization, objectivation, and internalization.

AK, SR and IF as individuals experience externalization to express themselves who are social beings. The social interaction that occurs in externalization forms an institutionalized pattern and is internalized by AK, SR and IF as one of the guidelines in community life in Kudus with its kretek culture.

$\mathrm{AK}$ and IF who work as lecturers with the level of education Masters and SR who work as private employees with high school education course has its own pattern in interacting. The stock of knowledge and life experiences of AK, IF and SR make them less susceptible to the general (objective) pattern of healthy concepts and illness. For them, the culture of kretek does not merely interfere with health and cause death (poison) but serves as a medicine (honey).

\section{Conclusion}

The concept of healthy and sick and kretek culture is a dynamic objective reality so that at any time can change to adjust the development of the times. Clove culture that continues to be suppressed and attacked with health issues in fact still able to survive because interpreted subjectively by informants. Kretek culture does not always and forever interfere with health and cause death (poison) but can be a medicine (honey) for humans.

\section{References}

Berger, Peter L. \& Thomas Luckmann. 1990. Tafsir Sosial atas Kenyataan: Risalah tentang Sosiologi Pengetahuan. Terjemahan Hasan Basari. Jakarta: LP3ES.

Ismaya, E.A., Wasino, Wasino., Astuti, Tri Marhaeni P., and Soesilowati, Etty. 2018. The Meaning Of Kretek Culture For Kudus Society. Man In India, 98 (1) : 115-128.

Maman, Rachman. 2015. Lima Pendekatan Penelitian. Yogyakarta: Magnum Pustaka Utama.

Margana, S dkk. 2014. Kretek Indonesia: Dari Nasionalisme hingga Warisan Budaya. Yogyakarta: Jurusan Sejarah FIB UGM bekerjasama dengan PUSKINDO.

Ngangi, Charles R. 2011. Konstruksi Sosial Dalam Realitas Sosial. ASE 7 (2) pp 1-4.

Santosa, Iman Budhi. 2012. Ngudud cara orang Jawa menikmati hidup. Yogyakarta: Manasuka.

Supratno, Edy. 2016. Djamhari Penemu Kretek. Yogyakarta: Pustaka Ifada. 